\title{
Determinants of individual academic achievement - Group selectivity effects have many dimensions
}

Citation for published version (APA):

Zwick, T. (2013). Determinants of individual academic achievement - Group selectivity effects have many dimensions. ROA. ROA Research Memoranda No. 003 https://doi.org/10.26481/umaror.2013003

Document status and date:

Published: 01/01/2013

DOI:

10.26481/umaror.2013003

Document Version:

Publisher's PDF, also known as Version of record

\section{Please check the document version of this publication:}

- A submitted manuscript is the version of the article upon submission and before peer-review. There can be important differences between the submitted version and the official published version of record.

People interested in the research are advised to contact the author for the final version of the publication, or visit the DOI to the publisher's website.

- The final author version and the galley proof are versions of the publication after peer review.

- The final published version features the final layout of the paper including the volume, issue and page numbers.

Link to publication

\footnotetext{
General rights rights.

- You may freely distribute the URL identifying the publication in the public portal. please follow below link for the End User Agreement:

www.umlib.nl/taverne-license

Take down policy

If you believe that this document breaches copyright please contact us at:

repository@maastrichtuniversity.nl

providing details and we will investigate your claim.
}

Copyright and moral rights for the publications made accessible in the public portal are retained by the authors and/or other copyright owners and it is a condition of accessing publications that users recognise and abide by the legal requirements associated with these

- Users may download and print one copy of any publication from the public portal for the purpose of private study or research.

- You may not further distribute the material or use it for any profit-making activity or commercial gain

If the publication is distributed under the terms of Article $25 \mathrm{fa}$ of the Dutch Copyright Act, indicated by the "Taverne" license above, 
1) Maastricht University

Research Centre for Education and the Labour Market | ROA

\section{Determinants of individual academic achievement Group selectivity effects have many dimensions}

Thomas Zwick

\section{ROA Research Memorandum}

ROA-RM-2013/3

Research Centre for Education and the Labour Market Maastricht University

P.O. Box 616, 6200 MD Maastricht, The Netherlands

$\mathrm{T}+31433883647 \mathrm{~F}+31433884914$

secretary-roa-sbe@maastrichtuniversity.n www.roa.nl 


\section{Determinants of individual academic achievement Group selectivity effects have many dimensions}

Thomas Zwick

ROA-RM-2013/3*

March 2013

Research Centre for Education and the Labour Market

Maastricht University

P.O. Box 616, 6200 MD Maastricht, The Netherlands

$\mathrm{T}+31433883647 \mathrm{~F}+31433884914$

secretary-roa-sbe@maastrichtuniversity.nl

www.roa.nl

\footnotetext{
* The ROA Research Memorandum Series was created in order to make research results available for discussion, before those results are submitted for publication in journals.
} 


\section{Abstract}

\section{Determinants of individual academic achievement}

Group selectivity effects have many dimensions**

This paper measures determinants of individual academic achievements. In addition to an extensive list of individual characteristics, skills obtained during study and socioeconomic background factors, many dimensions of selectivity into academic study subjects are shown to drive individual academic achievement, such as differences between average student grades during tertiary education or cognitive skills. This paper is based on a large and representative graduate survey of graduates in the academic year 2003/2004 in the German state of Bavaria.

JEL classification: 121, 123

Keywords: academic achievement, selectivity effects, graduates

Thomas Zwick

University of Würzburg

Faculty of Economics and Management

Sanderring 2

D-97070 Würzburg

Germany

thomas.zwick@uni-wuerzburg.de

** I thank Roxanne Korthals, Christoph Meng, and Robert Wagner for helpful comments and the Staatsinstitut für Schulqualität und Bildungsforschung, Munich and especially Susanne Falk for providing me with the first wave of the Bayerisches Absolventenpanel and giving me advice on its interpretation. 


\section{Introduction}

Many studies have investigated determinants of individual academic success. These are frequently based on large-scale graduate surveys conducted by universities or research institutes. The surveys usually cover graduates from several study subjects or fields of study and they are strongly increasing in number. ${ }^{1}$ The literature on drivers of academic success has established a couple of correlations, which have been replicated in many countries, contexts and data sets. We know, for example, that individual characteristics such as previous school achievements, assessments of capabilities or study motivation, are positively correlated with academic success. In addition, socio-economic background, and particularly parental academic achievements, has a measurable positive impact on the academic achievements of students (Ewijk and Sleegers, 2007). Finally, student peers and selection into study subjects have also been identified as important drivers of academic success.

This paper replicates many of these correlations. More specifically, it seeks to identify determinants of grades obtained at the end of an academic study. However, it shows that some bivariate correlations disappear when additional factors are controlled for. In addition, this paper concentrates on a novel point. It analyses several indicators of selectivity into academic study subjects by looking at the impact of many average student characteristics on individual grades. It shows that average student characteristics widely differ between study subjects, and that some characteristics have an impact on students' academic achievements in addition to the direct individual effect. These peer effects might be the consequence of more able pupils self-selecting themselves into specific academic subjects. Finally, differences in determinants of academic achievement between more and less "academic" grades are shown by differentiating between grades obtained from universities and universities of applied sciences (polytechnic schools/Fachhochschule).

\footnotetext{
${ }^{1}$ For example, a large number of graduate surveys are coordinated by Kooperationsprojekt Absolventenstudien (KOAB) in Kassel, Germany or AG Hochschulforschung in Konstanz, Germany. Since 2007, the Kooperationsprojekt has surveyed more than 100,000 students from more than 60 higher education institutions in Germany, the AG Hochschulforschung surveys between 7,000 and 10,000 German students in a two-year and three-year cycle since 1982 (Grave, 2011). Leitner (2009) provides a good survey of the large number of graduate surveys in Germany. Another large graduate survey data collection is the "Higher Education and Graduate Employment in Europe" (CHEERS) survey with more than 30,000 graduates from 11 European countries, compare Lindberg (2007) or García-Aracil et al. (2007).
} 
The findings on the impact of group characteristics imply that academic success very much depends on with whom you compete in your academic field. Therefore, average student information on several relevant dimensions such as average analytical skills or average grades in secondary school education should be included when individual determinants of academic success are measured. Average student information can (and should) be added in the analysis of graduate surveys that include students from several academic study fields. Finally, self-assessed skills obtained during the study period are included as determinants of academic success. The inclusion shows that written expression skills are more important than oral expression or foreign language skills for academic success. Analytical skills and specific knowledge also have a positive impact on grades in contrast to broad basic and theoretic knowledge or boundary spanning. Independent work skills are positively correlated with success in contrast to co-operation and communication skills. This contribution is based on a large-scale and representative data set of all graduates from academic institutions in the German state of Bavaria in the academic year 2003/2004.

The paper is organised as follows. In the next section, the literature on determinants of academic achievement is surveyed with a focus on evidence for Germany. The third section explains the empirical strategy pursued and what is new in relation to the literature. The fourth section presents the data and some descriptive statistics. The fifth section shows the empirical results on drivers of academic success and their implications. The sixth section concludes.

\section{Background}

Grades awarded to individuals at the end of an academic study are important indicators of ability and productivity when those individuals look for their first jobs. Consequently, many papers have shown a positive correlation between grades at university and entry wages as well as productivity (Wise, 1975; Rumberger and Scott, 1993).

Another important dimension for academic achievement is a student's socio-economic background. Typical conceptualisations of the socio-economic background of students are qualification and professional status of peers' parents, home resources, number of books, 
and internet, communication and information technology at home (Sirin, 2005). This contribution includes parental professional education ${ }^{2}$ and home resources measured by the main means used to cover living costs during the study period. ${ }^{3}$ However, so-called cultural resources such as complex and abstract language skills or self-confidence, might be more important for academic success and might be more frequently provided than home resources by parents with an academic background.

A frequent topic in the literature on determinants of academic achievements is differences between the sexes (Dayioglu and Türüt-Asik, 2007). In descriptive statistics, females are usually more successful in school and at university in Germany (Erdel, 2010) - on average, females attain a higher school level and obtain better grades. Another individual characteristic related to academic achievement is having been born in a foreign country (Nauck et al., 1998). Students with a migrant background frequently have a weaker language background, which may make it difficult to obtain good grades in Germany as most academic subjects are more or less completely taught and examined in German.

Many studies show that students with better grades in their final school exams also obtain better grades in their academic studies (Jirjahn, 2007; Erdel, 2010; Dooley et al., 2012). Reasons for this might be that good school grades reveal high intrinsic motivation, individual (otherwise unobservable) capabilities and parental input during the period before the academic study. In addition, school grades determine which academic subjects can be studied (in Germany, several subjects have a so-called numerus clausus or in other words only allow students with sufficiently good school grades). ${ }^{4}$ In an international comparison including the Czech Republic, Great Britain, Norway, and Austria, Trapmann et al. (2007) demonstrate, using a meta analysis, that German school grades have the highest prediction power for academic achievement. In Bavaria and other German states with central final school examinations, the Abitur grade might have an even higher informational value on ability and future academic achievement because the questions in the final school

\footnotetext{
${ }^{2}$ The highest school grade of parents also is available from the data. However, it is very closely correlated with professional education and therefore is not included because the information does not offer any additional insights.

${ }^{3}$ Besides mainly receiving money from parents, working, receiving a grant, public subsidies and having a bank loan are considered.

${ }^{4}$ In general, sorting into subjects is mainly determined by school grades.
} 
examinations are the same for all graduates in one year and the answers are double-checked by several teachers in order to ensure comparable grading. ${ }^{5}$

An additional degree from apprenticeship training might also influence academic achievement. About $20 \%$ of German apprentices hold an entrance licence for an academic study (Abitur or comparable), and more than one-fifth of students have a degree obtained from an apprenticeship programme (BMBF, 2012). In contrast to most other countries (an exception are the Netherlands), it is not uncommon in Germany for many students to take on a second professional degree after having obtained a more practical occupational apprenticeship degree. There is evidence that students with a double degree might have obtained knowledge and skills during their apprenticeship they can use for their academic studies. In addition, these students might be more determined to obtain a good study certificate because their outside options (financial losses during their studies) are higher and they consciously decided to obtain a higher professional degree after having experienced the alternative labour market options for skilled employees. For example, Pilz (2009) finds that students who have completed apprenticeship training in the financial sector have a stronger career determination than students without an apprenticeship degree.

These are additional hypotheses on the correlation between individual characteristics and academic achievements: Graduates who are younger than their peers with the same study length might have better grades because they demonstrated efficiency in studying and career determination (young age is still seen as a positive trait when applying for a job), see Billari and Pellizzari (2012). Analogously, relatively old graduates should have worse grades than their peers of an intermediate age. The study length might be an additional indicator for intrinsic motivation. An especially long study period might be negatively correlated with academic achievements (Grave, 2011). Having studied abroad, in contrast, might be an indicator for a positive intrinsic motivation. In addition, students might have learnt more when they have been exposed to more than one university system and they might have achieved additional skills in self-organisation (Holoviak et al. ).

\footnotetext{
${ }^{5}$ About $75 \%$ of Bavarian students, on average, obtained their university entrance exam in Bavaria, see Bayerisches Landesamt für Statistik und Datenverarbeitung (2011).
} 
Besides measurable individual characteristics, self-assessed perceived ability in certain relevant dimensions, such as reading and writing skills or social skills gained during the study spell, also might play a role in determining differences between diploma grades (Cassidy, 2011). These differences show which skills are rewarded in academic education and which skills do not have an important role in academic achievements. In addition, self-assessed skills might capture otherwise unobservable differences between students. The data set used in this study has the big advantage of an exceptionally rich list of self-assessed skills categories.

Finally, the average characteristics of students in the study field might have an important impact on absolute and relative individual academic achievement (Coleman, 1966; Henderson et al., 1978). ${ }^{6}$ Students educate both themselves and each other, and the quality of the education any student gets depends in good measure on the abilities of that student's peers (Winston, 1999). The socio-economic status of peers and average grades peers received in school or earlier during their academic study commonly are used as influence indicators (McEwan, 2003; Van Ewiijk and Sleegers, 2007). In this paper, not only are these measures included as indicators of peer quality, but also an extensive list of other aggregated individual characteristics by study subject.

Peers and the characteristics of fellow students are crucial in school and academic education because students can prevent their fellows from learning by disturbing class or otherwise determine the scope of the class and therefore the difficulty of obtaining relatively good grades (Lazear, 2001). For schools, peer effects are an important topic because pupils usually interact more closely in class over a long time and changes in class composition and teachers are rare and can be tracked over time. In addition, institutional rules determine whether pupils can self-select into certain schools or classes, whether the institution determines who gets into a class or whether class composition is completely independent of ability or previous grades. Therefore, ability grouping (or tracking) for pupils is an interesting topic for educational policy (Hanushek et al., 2003). However, this is not a political issue for academic education because self-selection into academic subjects cannot be avoided and is partly

\footnotetext{
${ }^{6}$ This impact is termed differently in different disciplines (peer effect, compositional effect, contextual effect), although the underlying principle is the same (Van Ewijk and Sleegers, 2007).
} 
forced by institutional rules such as a numerus clausus for subjects with a demand surplus. In addition, the composition of the student body varies across courses in Germany, obligatory study groups are rare and most students therefore study individually or in self-chosen and small study groups of which the composition can change across courses. Peer effects for students' relative performance in a cohort are therefore probably less influenced by direct interaction with other students but by selectivity effects according to subject choice. It is easier to obtain better than average grades when fellow students are less devoted to studying or less able independent of direct interaction effects between students. I therefore argue that interaction effects on academic education can only be measured when we know about personal interaction behaviour such as that of roommates or fraternity members (Hall and Willerman, 1963; Sacerdote, 2001; Zimmerman, 2007). In our data set - as is usually the case with graduate surveys - there is only information on fellow students' characteristics, not on who interacts with whom. Therefore, I prefer to define group interaction effects as 'selectivity effects' here.

Most studies on peer/selectivity effects look at the impact on absolute performance such as standardised tests (PISA, PIRLS, etc.). An empirical issue of measuring peer or selectivity effects is to disentangle self-selection into certain groups and the genuine peer/selectivity effect within a group (Evans et al., 1992) - this is called the endogeneity or simultaneity problem. Remedies proposed for endogeneity are fixed effects regressions, natural experiments, instrumental variables regressions or the use of lagged achievement measures. Hanushek et al. (2003), McEwan (2003) and Sund (2009), for example, show using fixed effects regressions that better peers increase absolute performance of pupils. Kiss (2011) uses a natural experiment with exogeneously changing peers between school grades in order to show that good peers are a positive driver of absolute pupil grades. Evans et al. (1992) use background variables such as metropolitan area unemployment rate, median family income and the regional percentage of adults who completed college as instruments to explain the peer effects on teenage pregnancy and school drop-out. Hanushek et al. (2003) use lagged achievement measures or predetermined fellow student variables correlated with achievement measures such as the number of books at home or the academic achievements of parents (Ammermüller and Pischke, 2006; McEwan, 2003). This paper includes average final school grades in a subject (usually the university entrance exam) 
as an indicator of ability and school background before the university study with fellow students.

Some studies ask directly about subjective assessment of peer influence on grades (Santor et al., 2000), most include average grades (and sometimes their variance) of fellow students (Henderson et al., 1978; Kiss, 2011) and some also include selected additional characteristics such as the share of students of migrant background (Sund, 2009) or the share of female students in an academic subject (Dayioglu and Türüt-Asik, 2007). This paper systematically takes all average characteristics of fellow students into account as determinants of academic success, and shows that selectivity effects have more dimensions than those shown in previous studies.

In Germany, selection into different institutions such as a university or university of applied sciences where the same subjects can be studied also plays a role. Although variance within universities or universities of applied sciences might be low with respect to quality of students and quality of education, idiosyncratic influences on grades in certain institutions cannot be excluded. Therefore, institution fixed effects are controlled for in order to account for any endogeneity induced when students choose a specific institution because of the peers they might encounter there or differences in the quality of grades awarded (McEwan, 2003).

Based on these considerations, our empirical model of determinants of deviations from the subject mean of academic grades includes:

- individual characteristics: gender and age

- socio-economic background: father and mother having university degrees

- indicator for subject selectivity, ability and inputs before the study began: final grades in school

- indicator for career determinedness: completed apprenticeship 
- inputs during the study: study financing mode, study length, study abroad, selfassessed ability in 15 different dimensions at the end of study ${ }^{7}$, child before end of study

- selectivity effects: average characteristics of students in the same subject in all dimensions mentioned above

- fixed institutional effects: dummies for all universities/universities of applied sciences included in study.

\section{Empirical approach}

Academic achievement is measured as self-reported cumulative grade point average. In Germany, this is the average of the final grades of all courses relevant for graduation. They are measured between $1.0=$ excellent and $4.0=$ sufficient (this means the lower the grade, the better) and consist of several written and oral exams and the final student thesis taken with several instructors/professors over a long time period at the end of the study. In order to control for large differences between average subject grades (see Appendix Table A2), it is not the absolute grade which is taken as the dependent variable but the deviation from the average grade per subject (Kiss, 2011). In addition, idiosyncratic differences between subjects and the risk of heterogeneity in variances between subjects are captured using variance clustering at the subject level.

To control for unobserved heterogeneity, a necessary assumption is that the final school grade $T_{i, 0}$ sufficiently captures all previous school, peer, ability and family inputs (Sund, 2009). Vector $X_{i, 0}$ is a set of additional individual explanatory variables for achievement growth during the academic study such as study length, perceived skills at the end of study and study financing mode. Selectivity effects are measured by average individual characteristics of students and their socio-economic background per subject $X_{-i, 0}:^{8}$

$$
T_{i, 1}=f\left(T_{i, 0}, X_{i, 0}, X_{-i, 0}\right)
$$

\footnotetext{
${ }^{7}$ The precise question is: Did you have the following skills at the end of your study? Answers were given on a five-point scale from "to a high degree" until "to a very low degree/not at all".

${ }^{8}$ The subscript $-i$ denotes characteristics of all other students in subject $u$.
} 
For the regression, the use of institution fixed effects by adding dummy variables for all institutions $c$ captures initial sorting into institutions (McEwan, 2003). Demeaning of grades with respect to subjects is denoted by subscript $u$. Therefore, the final estimation equation is:

$$
T_{i u, 1}=\alpha_{0}+\alpha_{1} T_{i u, 0}+\alpha_{2} X_{i u, 0}+\alpha_{3} X_{-i u, 0}+\alpha_{4} C_{u}+\varepsilon_{i u, 1} .
$$

This regression is performed for the entire sample, and for university diploma graduates only.

\section{Data and sample characteristics}

This paper uses the Bavarian Graduate Panel (BAP, Bayerisches Absolventenpanel, for details see Falk et al., 2007). All ${ }^{9} 13,200$ graduates in the academic year 2003/2004 in all Bavarian public universities and universities of applied sciences (Fachhochschule) were contacted by mail or internet during the period November 2005-March 2006. Only graduates with a diploma or magister were included in the survey (only very few students with the consecutive bachelor or master degrees graduated from German universities in this period). In addition, subjects with (additional) state examinations such as law, medicine or teaching professions were excluded. The reply ratio was about 35\% - 4,573 graduates sent back their completed questionnaires (most by mail and about $5 \%$ online). The answers are fully representative of all graduates in Bavaria in the subjects included. This was checked by comparing the subject shares in the answers with the number of graduates in the full sample (Falk et al., 2007). The graduates who answered the questionnaire had somewhat better grades and studied a little quicker. Both deviations from the full sample characteristics were not significant, however ${ }^{10}$. In addition, sufficient observations from all academic institutions were obtained in order to include dummy variables for each institution.

\footnotetext{
${ }^{9}$ Only graduates in those subjects with more than 100 graduates in the academic year 2003/2004 were included.

${ }^{10}$ The sample averages in grades and study length were $10.04(1.93)$ and $1.93(0.52)$, and the respective full sample averages were 10.75 (2.11) and 2.06 (0.56), standard deviations in brackets.
} 
From the original list of 62 subjects, three subjects ${ }^{11}$ were dropped because they had too few graduates. The remaining subjects were combined into 16 subject groups. In more detail, the 21 engineering subjects such as mechanical engineering, construction engineering, electronic engineering, interdisciplinary studies with focus on engineering, and engineering and management were merged into "engineering" after checking that all subjects were homogeneous with respect to observables. In addition, several subspecialisations in management, mathematics and physics, biology/chemistry and sociology/political science were merged as well as foreign language sciences (mainly English language and literature studies) and interdisciplinary studies with focus on languages. The number of all observations per subject and of all university diploma graduates per subject can be found in Table $A 1$ in the appendix.

Students in the sub-sample of university diploma graduates had somewhat better grades at school than those in the full sample. However, fewer university diploma graduates additionally obtained a dual apprenticeship degree. The share of females and students with children is comparable in the full sample and the sub-sample of university diploma graduates. University diploma graduates obtained the means for their living more frequently from their parents and less frequently from work or a public loan than those in the full sample, see Table 1.

In Germany, there are several ways to obtain admission to universities and universities of applied sciences. The most traditional route is graduation from a grammar school (Gymnasium) with the Abitur. However, this route has become less common over time. In our data, $70 \%$ of university or university of applied science graduates had graduated from a grammar school (96\% of university diploma graduates held an Abitur). The other graduates were awarded permission to study from another school or did not hold the Abitur certification. Some graduates, for example, hold only the so-called Fachhochschulreife (this is permission to study only at a university of applied sciences and sometimes only a certain range of subjects) or other evidence that they will be able to keep up with their fellow students.

\footnotetext{
${ }^{11}$ These were: interdisciplinary studies with focus on law, design and other subjects with together 34 graduates.
} 


\begin{tabular}{|c|c|c|c|}
\hline Variable & $\begin{array}{l}\text { Mean } \\
\text { (all) }\end{array}$ & $\begin{array}{c}\text { Mean } \\
\text { (university } \\
\text { diploma } \\
\text { graduates) }\end{array}$ & Variable explanation \\
\hline Individual characteristics & & & \\
\hline Female & 0.45 & 0.42 & Share of female graduates \\
\hline Father university education & 0.27 & 0.48 & Share of fathers with university education \\
\hline Mother university education & 0.16 & 0.36 & Share of mothers with university education \\
\hline Final grade at school & 2.3 & 2.1 & $\begin{array}{l}\text { Grade at final higher secondary education } \\
\text { exam (from } 1.0=\text { excellent to } 4.0= \\
\text { sufficient) }\end{array}$ \\
\hline Age at graduation: young & 0.10 & 0.07 & $\begin{array}{l}\text { Graduate was less than } 24 \text { years old at } \\
\text { graduation }\end{array}$ \\
\hline Age at graduation: old & 0.19 & 0.16 & Graduate was more than 27 years old \\
\hline Grammar school (Abitur) & 0.70 & 0.94 & $\begin{array}{l}\text { Graduate has school leaving certificate } \\
\text { from grammar school instead of more } \\
\text { indirect academic study allowance }\end{array}$ \\
\hline Dual apprenticeship degree & 0.29 & 0.18 & $\begin{array}{l}\text { Graduate has degree from dual } \\
\text { apprenticeship training }\end{array}$ \\
\hline More than 11 semesters studied & 0.33 & 0.48 & $\begin{array}{l}\text { Study took more than } 11 \text { semesters before } \\
\text { graduation }\end{array}$ \\
\hline Study abroad & 0.39 & 0.13 & $\begin{array}{l}\text { Graduate undertook part of the study } \\
\text { outside Germany }\end{array}$ \\
\hline Child & 0.07 & 0.06 & $\begin{array}{l}\text { Graduate had own child at date of } \\
\text { graduation }\end{array}$ \\
\hline Living: employment & 0.33 & 0.26 & $\begin{array}{l}\text { Main source for living is being dependently } \\
\text { employed }\end{array}$ \\
\hline Living: state loan & 0.11 & 0.09 & Main source for living is state loan (Bafoeg) \\
\hline Living: grant & 0.03 & 0.04 & Main source for living is grant \\
\hline Living: parents & 0.43 & 0.54 & Main source for living is parental payments \\
\hline Living: bank credit & 0.01 & 0.01 & Main source for living is bank credit \\
\hline \multicolumn{4}{|l|}{ Self-assessed skills } \\
\hline Broad basic knowledge & 0.21 & 0.23 & \multirow{15}{*}{$\begin{array}{l}\text { Dummy = } 1 \text { if graduate chose } 1 \text { on scale } \\
\text { between } 1 \text { (to a high degree) and } 5 \text { (to a } \\
\text { low degree/not at all) }\end{array}$} \\
\hline Specific knowledge in my study field & 0.19 & 0.23 & \\
\hline $\begin{array}{l}\text { Theoretical knowledge in my study } \\
\text { field }\end{array}$ & 0.19 & 0.24 & \\
\hline Knowledge in scientific methods & 0.15 & 0.21 & \\
\hline Foreign languages & 0.13 & 0.15 & \\
\hline Independent work & 0.47 & 0.51 & \\
\hline Communication skills & 0.25 & 0.25 & \\
\hline Problem solving skills & 0.25 & 0.29 & \\
\hline Organisation skills & 0.31 & 0.33 & \\
\hline $\begin{array}{l}\text { Information and communication } \\
\text { technology skills }\end{array}$ & 0.25 & 0.25 & \\
\hline Written expression skills & 0.23 & 0.24 & \\
\hline Oral expression skills & 0.19 & 0.20 & \\
\hline Co-operation skills & 0.20 & 0.21 & \\
\hline Boundary-spanning thinking & 0.21 & 0.22 & \\
\hline Analytical skills & 0.27 & 0.35 & \\
\hline Number of observations & 4271 & 1985 & \\
\hline
\end{tabular}

In universities of applied sciences, students attend most courses together, graduate (more or less) together and have little choice in their schedule. The traditional diploma and magister 
structure at universities (and to a lesser extent the new bachelor and master structure) requires more individual choice from a curriculum comprising mainly theoretical subjects and self-organisation skills. To get on-the-job experience, internship semesters are a mandatory part of study at a Fachhochschule. Therefore, it is likely that students at universities of applied sciences are better trained in transferring learned knowledge and skills into practice, whereas students at universities are better trained in method development and self-organisation. University diploma graduates are more confident about their skills at the end of their studies - the largest differences in perceived skills are in analytical skills, scientific methods and theoretical knowledge in their field of study, see Table 1.

Please note that average absolute grades at the end of the academic study are better than average grades at the end of schooling (compare the first two rows in Table A2). This is in contrast, for example, to Canada where university students at least during their first years get, on average, poorer grades than when in school (Wintre et al., 2011). This again shows idiosyncratic traditions in grading in different schooling institutions.

\section{Empirical results}

First, a couple of important bivariate correlations between variables are discussed. The individual correlation between school and university grades is 0.42 (the significance of the correlation is less than $1 \%$ - see Table 2). Also, achievement at higher secondary school is one of the main predictors of academic achievement in the multivariate regressions below (see also Jirjahn, 2004). This shows that ability and skills obtained in school must be included in order to avoid an overestimation of factors acquired during the study period. Please note that the correlation is clearly lower between final school grades and the deviation from university subject grades (0.35) than between school grades and absolute university grades. This is a consequence of less academically able pupils self-selecting into subjects with a higher share of other pupils with lower school grades, see the discussion on differences between subjects and self-selection below.

In descriptive statistics, it is frequently found that female students obtain better (i.e. lower) grades than male students (Erdel, 2010). This is also the case in our data set - on average, 
female graduates obtain a grade of 1.88 (SD: 0.51), which is significantly better than the average grade of male graduates $(1.97, \mathrm{SD}: 0.53) .{ }^{12}$ This difference is also found in the bivariate correlation between grades and gender (see last line in Table 2).

\begin{tabular}{l|c|c}
\hline Variable & School grade & University grade \\
\hline Final school grade & & $0.42^{* * *}$ (absolute grade) \\
Final school grade & & $0.35^{* * *}$ (deviation from mean) \\
Father university education & $-0.15^{* * *}$ & $-0.10^{* * *}$ \\
Mother university education & $-0.15^{* * *}$ & $-0.08^{* * *}$ \\
Gender & $-0.12^{* * *}$ & $-0.17^{* * *}$ \\
\hline
\end{tabular}

Table 2: Bivariate correlations between school/university grades and the individual/socio-economic characteristics of graduates. Grades are measured as deviation from subject mean besides in first line. Number of observations: 4282 . Significance levels: $* * *<0.01$.

There is also a strong positive bivariate correlation between parental academic education and school grades. In addition, the correlation between grades and academic achievement of the mother is comparable to the corresponding correlation of the father, see Table 2. Finally, it can also be shown that a stronger parental academic background leads to a higher self-perception of own relevant skills. ${ }^{13}$

Next, differences between academic subjects with respect to average grades and student characteristics are discussed. Average school grades and academic grades are, of course, also positively correlated between subjects (bivariate correlation is: $0.76^{* * *}$, significance level<0.01). Graduates in subjects with a better than average final grade are more likely to have mothers (the correlation is $\left.0.55^{* * *}\right)$ and fathers $\left(0.56^{* * *}\right)$ with an academic degree and are more frequently female $\left(0.34^{* * *}\right)$. This analysis is based on the deviations from subject means in multivariate regressions and therefore the level effect between better average final grade and a higher share of parents with academic background cancels out later.

\footnotetext{
12 The difference between males and females is even larger in the final school examination grades (females 2.21 (SD: 0.57), males 2.34 (SD: 0.61)).

${ }^{13}$ Most bivariate correlations between parental academic education and students' self-assessed skill levels are significantly positive. The highest correlations of fathers' and mothers' university education are for foreign languages, communication, problem solving and analytic skills. Insignificant are broad basic knowledge and ICT. There are no significant differences between father's and mother's academic achievements.
} 
In multivariate regressions (see the first two columns in Table 3) that explain the deviation from subject mean final grade, the impact of the final grades in school is smaller than in the bivariate case but final grades still are one of the main drivers of academic success (see Dooley et al., 2012). The multivariate correlation between school grade and academic achievement is somewhat lower than that reported in a recent meta-analysis by Trapmann et al. (2007) for Germany ${ }^{14}$. An important reason for the smaller correlation might be that the present study includes a large number of additional covariates, and that the studies included in the meta-analysis included mainly bivariate correlations.

The bivariate difference in academic achievements between male and female pupils and students found in Table 2 vanishes in the multivariate approach. This finding is familiar from other studies (see, for example, Jirjahn, 2004 or Cassidy, 2011). One reason for the differences between male and female students is the choice of "male" and "female" subjects (García-Aracil et al., 2007). Females more often choose subjects where students get relatively good final grades on average (such as psychology or social work, see Table A2 in the appendix). Another reason is differences in final school grades between males and females. The gender differences in academic achievements therefore vanish when we take into account differences in average subject grades and other explanatory variables.

Interestingly, a certificate from a grammar school (Abitur) instead of more indirect routes to higher education does not have an impact on grades. When a student was especially young (younger than 24 years) at the date of graduation, the grades were significantly better, but when an applicant was especially old (older than 27 years), the grades were significantly worse. In addition, those graduates who took more than 11 semesters to graduate had significantly worse grades. Age at graduation and study length might be indicators for intrinsic study motivation or ability. ${ }^{15}$ An additional apprenticeship degree improves the academic achievement significantly - this indeed might be a sign of a higher career determination (double degree). Study abroad (which also might be a signal for higher motivation) has a significantly positive impact on grades.

\footnotetext{
${ }^{14}$ In a comparable meta-analysis of 20 studies, Peers and Johnston (1994) found an overall correlation of 0.28 between A-level grades and final degree performance in Great Britain.

${ }^{15}$ Please note that age and study length is highly correlated with a correlation coefficient of $0.35^{* * *}$.
} 
Academic achievement of fathers and mothers no longer has any impact using the multivariate approach. One reason might be that socio-economic background also has an impact on the choice of the academic field of study (Hansen, 1997) - see the large differences in average shares of parents' academic education by subject in Table A2. The way students earn their living has the expected impact on grades. Students who have to work during the semester and mainly finance their living by working have significantly worse grades. Students who obtained a grant (which frequently is based on good school grades or a positive assessment test of academic skills) do not have significantly better grades.

It is also interesting to note that high self-assessed specific knowledge in the study field yields significantly better grades in contrast to broad basic knowledge and theoretical knowledge in the study field and knowledge of scientific methods. Clearly, mainly subjectspecific knowledge is tested in contrast to basic knowledge in academic exams. Written expression, independent work and analytical skills are drivers of good grades in contrast to oral and communicative skills such as co-operation, boundary-spanning, oral expression, foreign languages or communication skills. This may be a consequence of the fact that most exams are written individually and few grades can be obtained by oral tests or teamwork. In line with the discussion by Cassidy (2011), proficiency in computer use does not lead to better grades - this might reflect the fact that computers do not play a large role in academic education. 


\begin{tabular}{|c|c|c|c|}
\hline & (1) & (2) & (3) \\
\hline \multicolumn{4}{|l|}{ Individual characteristics } \\
\hline \multirow[t]{2}{*}{ Final school grade } & $0.242^{* * *}$ & $0.268^{* * *}$ & $0.280 * * *$ \\
\hline & $(0.015)$ & $(0.019)$ & $(0.021)$ \\
\hline \multirow[t]{2}{*}{ Father university degree } & -0.012 & -0.016 & -0.010 \\
\hline & $(0.015)$ & $(0.015)$ & $(0.018)$ \\
\hline \multirow[t]{2}{*}{ Mother university degree } & 0.026 & 0.022 & $-0.040^{*}$ \\
\hline & $(0.028)$ & $(0.027)$ & $(0.022)$ \\
\hline \multirow{2}{*}{ Woman } & 0.007 & 0.002 & 0.014 \\
\hline & $(0.028)$ & $(0.017)$ & $(0.032)$ \\
\hline \multirow[t]{2}{*}{ Foreigner } & 0.063 & $0.070^{* *}$ & 0.003 \\
\hline & $(0.038)$ & $(0.034)$ & $(0.051)$ \\
\hline \multirow[t]{2}{*}{ Age at graduation: young } & $-0.050^{*}$ & $-0.045^{*}$ & -0.006 \\
\hline & $(0.025)$ & $(0.026)$ & $(0.025)$ \\
\hline \multirow[t]{2}{*}{ Age at graduation: old } & $0.102 * * *$ & $0.104 * * *$ & $0.103^{* * *}$ \\
\hline & $(0.022)$ & $(0.023)$ & $(0.037)$ \\
\hline \multirow{2}{*}{ Long study duration } & $0.160 * * *$ & $0.151^{* * *}$ & $0.101^{* * *}$ \\
\hline & $(0.023)$ & $(0.029)$ & $(0.020)$ \\
\hline \multirow[t]{2}{*}{ Child } & 0.072 & $0.077^{*}$ & $0.159^{* *}$ \\
\hline & $(0.043)$ & $(0.044)$ & $(0.059)$ \\
\hline \multirow{2}{*}{ Dual apprenticeship degree } & $-0.093 * * *$ & $-0.092^{* *}$ & $-0.070^{*}$ \\
\hline & $(0.022)$ & $(0.025)$ & $(0.041)$ \\
\hline \multirow[t]{2}{*}{ Study abroad } & $-0.091 * * *$ & $-0.101 * * *$ & $-0.124 * * *$ \\
\hline & $(0.018)$ & $(0.016)$ & $(0.031)$ \\
\hline \multirow[t]{2}{*}{ Grammar school degree } & -0.009 & -0.019 & $-0.132 * * *$ \\
\hline & $(0.020)$ & $(0.031)$ & $(0.039)$ \\
\hline \multirow[t]{2}{*}{ Living: employment } & $0.069 * * *$ & $0.072^{* * *}$ & $0.065^{* * *}$ \\
\hline & $(0.015)$ & $(0.015)$ & $(0.020)$ \\
\hline \multirow[t]{2}{*}{ Living: public subsidy } & 0.039 & 0.033 & 0.022 \\
\hline & $(0.025)$ & $(0.023)$ & $(0.048)$ \\
\hline \multirow[t]{2}{*}{ Living: study grant } & -0.052 & -0.053 & -0.029 \\
\hline & $(0.036)$ & $(0.036)$ & $(0.042)$ \\
\hline \multirow[t]{2}{*}{ Living: parents } & 0.025 & 0.023 & 0.029 \\
\hline & $(0.019)$ & $(0.022)$ & $(0.020)$ \\
\hline \multirow[t]{2}{*}{ Living: bank credit } & $0.095^{* *}$ & $0.084^{*}$ & 0.076 \\
\hline & $(0.043)$ & $(0.043)$ & (0.095) \\
\hline
\end{tabular}




\section{Self-assessed skills}

Broad basic knowledge

$\begin{array}{ccc}0.009 & 0.008 & 0.014 \\ (0.016) & (0.016) & (0.033) \\ -0.069 * * * & -0.073 * * & -0.069 * * \\ & & \\ (0.021) & (0.021) & (0.029) \\ -0.009 & -0.009 & -0.028\end{array}$

Theoretical knowledge in my

$-0.009$

$\begin{array}{lll}(0.014) & (0.016) & (0.021)\end{array}$

Knowledge in scientific methods

$\begin{array}{lll}0.013 & 0.012 & 0.011\end{array}$

(0.021) (0.020) (0.016)

Foreign languages

$0.057^{* * *} \quad 0.042 \quad 0.040$

$\begin{array}{lll}(0.020) & (0.026) & (0.024)\end{array}$

Independent work

$-0.048 * * * \quad-0.051 * * * \quad-0.046 * * *$

$\begin{array}{lll}(0.013) & (0.012) & (0.016)\end{array}$

Communication skills

$0.019 \quad 0.019 \quad 0.040 *$

$\begin{array}{lll}(0.019) & (0.018) & (0.021)\end{array}$

Problem solving skills

$\begin{array}{lll}-0.024 & -0.022 & -0.015\end{array}$

$\begin{array}{lll}(0.016) & (0.016) \quad(0.022)\end{array}$

Organisation skills

$0.026 \quad 0.024 \quad 0.046 * *$

(0.018) (0.017) (0.018)

Information and communication

$\begin{array}{lll}0.011 & 0.004 & -0.014\end{array}$

technology skills

Written expression skills

$\begin{array}{lll}(0.018) & (0.017) & (0.024)\end{array}$

$-0.088^{* * *} \quad-0.087^{* * *} \quad-0.084^{* * *}$

$\begin{array}{lll}(0.015) & (0.015) & (0.022)\end{array}$

Oral expression skills

$\begin{array}{lll}0.015 & 0.015 & 0.009\end{array}$

$\begin{array}{lll}(0.023) & (0.023) & (0.027)\end{array}$

Co-operation skills

$\begin{array}{lll}0.011 & 0.011 & 0.009\end{array}$

$\begin{array}{lll}(0.017) & (0.017) & (0.027)\end{array}$

Boundary-spanning thinking

$0.0220 .022 \quad 0.047^{*}$

Analytical skills

(0.019) (0.020) (0.026)

$-0.050 * * * \quad-0.048 * * * \quad-0.051 * *$

$\begin{array}{lll}(0.013) & (0.014) \quad(0.023)\end{array}$ 


\begin{tabular}{|c|c|c|c|}
\hline \multicolumn{4}{|l|}{$\begin{array}{l}\text { Average student characteristics } \\
\text { (selected selectivity effects) }\end{array}$} \\
\hline \multirow[t]{2}{*}{ Fathers with university education } & & 0.510 & -0.111 \\
\hline & & $(0.438)$ & $(1.324)$ \\
\hline \multirow[t]{2}{*}{ Mothers with university education } & & 0.113 & 0.301 \\
\hline & & $(1.038)$ & $(1.684)$ \\
\hline \multirow[t]{2}{*}{ Average number of semesters } & & -0.091 & -0.048 \\
\hline & & $(0.083)$ & $(0.077)$ \\
\hline \multirow[t]{2}{*}{ Average final school grade } & & $-0.284 * *$ & $-0.283 * *$ \\
\hline & & $(0.123)$ & $(0.123)$ \\
\hline \multirow{2}{*}{$\begin{array}{l}\text { Average share high problem } \\
\text { solving skills }\end{array}$} & & 0.198 & 0.281 \\
\hline & & $(0.452)$ & $(0.643)$ \\
\hline \multirow{2}{*}{$\begin{array}{l}\text { Average share boundary-spanning } \\
\text { skills }\end{array}$} & & -0.133 & -0.107 \\
\hline & & $(0.120)$ & $(0.225)$ \\
\hline \multirow[t]{2}{*}{ Average share high analytical skills } & & $0.363 * * *$ & $0.354^{*}$ \\
\hline & & $(0.138)$ & $(0.230)$ \\
\hline \multirow[t]{2}{*}{ Share students with study grant } & & 0.806 & 0.529 \\
\hline & & $(2.333)$ & (3.940) \\
\hline \multirow[t]{2}{*}{ Share students with bank credit } & & -2.931 & -0.263 \\
\hline & & (6.112) & $(1.816)$ \\
\hline \multirow[t]{2}{*}{ Constant } & $-0.536 * * *$ & 0.530 & 0.588 \\
\hline & $(0.050)$ & $(0.387)$ & $(1.453)$ \\
\hline 10 university dummies & Yes & Yes & Yes \\
\hline $\begin{array}{l}16 \text { university of applied sciences } \\
\text { dummies }\end{array}$ & Yes & Yes & No \\
\hline R-squared & $20.04 \%$ & $21.31 \%$ & $25.28 \%$ \\
\hline Observations & 4,250 & 4,250 & 1,930 \\
\hline
\end{tabular}

Table 3: Dependent variable: Deviation from subject mean ${ }^{16}$.

Standard errors in parentheses, adjusted by clusters by subject $(* * * p<0.01, * * p<0.05, * p<0.1)$, columns (1)-(3) full sample, column (4) only university diploma

One of the main topics in this paper is the inclusion of many different dimensions of selectivity effects. Selectivity effects can be controlled for in graduate studies with graduates from different subjects by aggregating individual graduate characteristics to the academic subject level. The aggregation of student characteristics to the subject level is an intermediate approach that takes into account that students do compete with their fellow students in the same subject and their interaction is much weaker than the interaction between pupils or fixed study groups or roommates in student dormitories. The competition from (and interaction with) students of other subjects is low, however, and therefore the impact of the inclusion of cohort effects that might capture changes in characteristics of the entire student body over time should be small.

\footnotetext{
${ }^{16}$ Note that the lower the average grade in Germany, the better the grade (the grade range is between $1=$ excellent and 4 = sufficient).
} 
To date, papers on academic achievements have included few selected average peer characteristics per subject. This paper systematically includes all average characteristics in order to test which characteristics have an impact on individual academic achievement and how average characteristics interact with other determinants. We distinguish between 16 subjects (clusters) and therefore cannot include too many variables at the subject aggregation level without risking multicollinearity. Most studies on the basis of graduate survey data include a limited number of subjects and therefore have to restrict the number of explanatory variables. Therefore, first only a sub-sample of peer dimensions as usually found in the literature is included: the share of students whose fathers and mothers have academic degrees and the average final grades of students in school. We find that it is harder to excel in subjects with many students who were successful in school, see column (1) in Table A3 in the Appendix. Share of fathers and mothers with university degrees does not have an impact on individual academic achievement, however. Interestingly, when additional average individual and socio-economic characteristics are added, school grades lose only a little of their explanatory power. In addition, average study length in the subject has a positive correlation with the chance of being better than the average student. All other peer characteristics are not significant, see column (2) in Table A3.

In separate regressions, the impact of average means of living and self-assessed knowledge per subject also are tested. Again, most of the individual influence factors that have a positive impact on individual academic achievement have a negative group effect - a high share of more able peers selecting themselves into a subject makes it harder for individual students to excel. Some significant factors lose their significance, however, some change their signs and a few gain significance. A high share of students with a perceived good knowledge in boundary spanning in a subject improves the academic achievements, a high share of students with high analytical skills and problem solving skills makes it harder to excel, see column (3) in Table A3. A high share of students with a study grant has a negative impact on academic achievement of their fellow students. ${ }^{17} \mathrm{~A}$ high share of students with a

\footnotetext{
${ }^{17}$ Note that a study grant may also be an indicator for high ability and good grades at the end of school. This correlation therefore should not be taken as a causal relationship.
} 
bank loan has a negative impact on individual grades - this means a positive impact on achievements because a higher grade is worse - see column (4) Table A3.

Next, the significant influences of all three lists of potential group effects (individual/socioeconomic characteristics; means of living; self-assessed knowledge) are combined in our preferred estimation model, which also includes all individual, socio-economic characteristics as well as institutional fixed effects, see column (2) in Table 3. Average school grades and a high share of students with high analytical skills remain significant peer characteristics, all other group characteristics are no longer significant. This indicates that group effects at the academic subject level are highly correlated. The direct correlations with individual characteristics and academic achievement are little affected by including group characteristics, compare columns (1) and (2) in Table 3. This means that individual and group characteristics are more or less orthogonal and both dimensions have separate explanatory power.

Some of the university and university of applied sciences dummies are significant (not shown here). ${ }^{18}$ This means that some institutions, on average, award better or worse grades than others even when observed individual, socio-economic and group factors are controlled for.

As a robustness check, the sample is reduced to graduates with a university diploma (Table 3, column (3)). The determinants for academic success are remarkably stable. The correlation between final school grade and university achievement is stronger. This is also found by Peers and Johnston (1994) for Great Britain. In addition, not having obtained a grammar school exam (Abitur) is now negatively correlated with academic grades, an additional indicator that grammar school prepares students better for the more theoretical study required for a university diploma than does alternative education routes. In the same direction points the significantly positive impact of having a mother with university degree. In the smaller sample, academic achievement of the mother plays a larger role than academic achievement of the father (McEwan, 2003; Jirjahn, 2007). Self-assessed skills and the way of making a living have more or less the same impact on academic achievements for

\footnotetext{
${ }^{18}$ Examples are significantly better grades awarded at Regensburg University or University of Applied Science in Landshut (having controlled for the other characteristics listed in Table 3).
} 
the smaller university diploma sample as for the full sample of graduates. Also the group effects are remarkably stable in both samples (this applies at least for the significant coefficients).

\section{Discussion}

This paper shows that academic achievement can be explained by individual, socio-economic and group characteristics. It proposes that besides the usual explanatory variables, such as gender, grades in tertiary education or study length, also perceived acquired skills and the means of making a living during the study period have a role in final academic grades. The paper also argues that it is important to control for differences between the grading traditions in academic subjects by demeaning grades by subject, and to control for institutional fixed effects. It uses final school grades as a measure of innate ability and inputs before studying. Finally, differences in the determinants for a good university diploma and other academic grades are analysed. The main contribution of this paper, however, is to show that group selectivity effects have different dimensions. It is not sufficient to control for single average student characteristics by subject such as average school grades or average shares of parents with academic degrees, as has mainly been done before. By systematically aggregating all individual characteristics of students to subject averages, it can be also shown that selectivity into subjects indicated, for example, by average study length and average self-assessed skills, has an important impact on individual academic achievements.

The analysis implies that mainly individual cognitive skills such as analytical skills, specific knowledge in the study field and independent work abilities positively affect academic success. Broad knowledge and theoretical knowledge do not lead to better grades. Also, teamworking skills such as co-operation skills, oral skills or foreign languages do not positively influence academic achievements in Germany. In addition, we also find a strong impact of selectivity on academic grades. The better the analytical skills of students in a subject on average and the better their grades in tertiary education, the smaller are the individual chances to excel in these subjects. Finally, correlations between gender, academic background of parents and individual academic achievements found in other studies may be 
spurious because they vanish when other determinants of grades at the end of an academic study are included.

This is mainly an exploratory study that uses already existing data. The data set is comparable to many other graduate surveys all over the world. It is interesting to explain deviations from final grade averages in an academic subject because students can successfully signal higher ability to the labour market when they have better academic grades from an academic institution (controlling for university type and location) than their competitors who are mainly students graduating from the same subject and institution.

One drawback of the data set is that it can only analyse achievements of graduates. We therefore cannot control for differences in selectivity of drop-outs during the study period that also might differ between subjects. The validity of the results hinges on the assumption that school grades depict ability and inputs obtained before the study period. Grades obtained in central examinations such as in the German states Bavaria, Baden-Württemberg, Hesse, Saxonia or Thuringia ${ }^{19}$ might indicate academic ability better than grades from decentral exams obtained from single schools. Unfortunately, we do not know which students obtained their university entrance qualifications from a Bavarian gymnasium. For future research, it therefore would help to reduce the sample to students with a comparable Abitur obtained in a state with central examinations. Finally, final grades from university have a positive impact on entry wages, but they might depict only a small range of competencies (Walberg and Weinstein, 1984).

This study lies between typical economists' studies on academic achievement that mainly focus on precise estimation of peer and selectivity effects, and social science studies that include a wide array of explanatory factors (Van Ewijk and Sleegers, 2007). The economic studies are typically more rigorous but they frequently include only a small set of explanatory and potentially informative covariates or they are confined to rather specific evaluation situations that allow the identification of causal effects. The social science studies include more explanatory variables and frequently have more representative data, and

\footnotetext{
${ }^{19}$ Other German states have introduced central examinations recently; however, most for selected subjects only.
} 
therefore might be more relevant for policy advice. However, as they frequently do not control (fully) for selection bias or simultaneity bias, they have a higher risk of reporting biased results. The coefficients of group effects on academic achievement are similar in studies from different disciplines. One reason might be that explicitly controlling for endogeneity and including additional mechanisms such as financial resources, self-assessed motivation or ability (coincidentally) both lead to a comparable reduction of estimation biases (Van Ewijk and Sleegers, 2007).

\section{Literature}

Ammermüller, A., Pischke, J. (2009). Peer Effects in European Primary Schools: Evidence from the Progress in the International Reading Literacy Study, Journal of Labor Economics 27 (3), 315-348.

Billari, F., Pellizzari, M. (2012). The Younger, the Better? Age Related Differences in Academic Performance at University, Journal of Population Economics 25 (2), 697-739.

BMBF (2012). Berufsbildungsbericht, Bonn and Berlin.

Bayerisches Landesamt für Statistik und Datenverarbeitung (2011). Zugereiste oder Einheimische? Die Herkunft von Erstsemestern an bayerischen Hochschulen, München.

Cassidy, S. (2012). Exploring Individual Differences as Determining Factors in Student Academic Achievement in Higher Education, Studies in Higher Education 37 (7), 793810.

Coleman, J. (1966). Equality of Educational Opportunity, Washington: Government Printing Office.

Dayioglu and Türüt-Asik (2007). Gender Differences in Academic Performance in a Large Public University in Turkey, Higher Education 53, 255-277.

Dooley, M., Payne, A., Robb, L. (2012): Persistence and Academic Success in University, Canadian Labour Market and Skills Researcher Network Working Paper 94.

Evans, W., Oates, W., Schwab, R. (1992). Measuring Peer Group Effects: A Study of Teenage Behavior, Journal of Political Economy 100 (5), 966-991.

Ewijk, R. van, Sleegers P. (2007) The Effect of Peer Socioeconomic Status on Student Achievement: A Meta-Analysis, Working Paper 20, Top Institute for Evidence Based Education Research, Amsterdam.

Falk, S., M. Reimer, L. Hartwig (2007). Absolventenforschung für Hochschulen und Bildungspolitik: Konzeption und Ziele des "Bayerischen Absolventenpanels", Beiträge zur Hochschulforschung 29 (1), 6-33.

García-Aracil, A., Gabaldon, D., Mora, J., Vila, L. (2007). The Relationship between Life Goals 
and Fields of Study among Young European Graduates, Higher Education 53, 843-865.

Grave, B. (2011). The Effect of Student Time Allocation on Academic Achievement, Education Economics 19 (3), 291-310.

Hall, R., Willerman, B. (1963). The Educational Influence of Dormitory Roommates, Sociometry 26 (3), 294-318.

Holoviak, J., Verney, T., Winter, A. and Holoviak, S. (2011). Assessing Academic Performance Through Study Abroad: Benefits of the Experience, Research in Higher Education Journal 11.

Henderson, V., Mieszkowksi, P., Sauvageau, Y. (1978). Peer Group Effects and Educational Production Functions, Journal of Public Economics 10 (1), 97-106.

Kiss, D. (2011). The Impact of Peer Ability and Heterogeneity on Student Achievement: Evidence from a Natural Experiment, IWQW Working Paper 02/11, University ErlangenNürnberg.

McEwan, P. (2003). Peer Effects on Student Achievement: Evidence from Chile, Economics of Education Review 22, 131-141.

Hansen, M. (1993). Sex Segregation in Higher-Education-Influence of Parents Educations and Social Background on Students Choice of Field, Tidsskrift for Samfunnsforskining 34 (1), 3-29.

Hanushek, E., Kain, J. Markman, J., Rivkin, S. (2003). Does Peer Ability Affect Student Achievement?, Journal of Applied Econometrics 18 (5), 527-544.

Hoxby, C. (2000). Peer Effects in the Classroom: Learning from Gender and Race Variation, NBER Working Paper 7867.

Jirjahn, U. (2004). Welche Faktoren beeinflussen den Erfolg im wirtschaftswissenschaftlichen Studium?, Zeitschrift für betriebswirtschaftliche Forschung 59, 286-313.

Lazear, E. (2001). Educational Production, Quarterly Journal of Economics 116 (3), 777-803.

Leitner, M. (2009). 35 Jahre Absolventenstudien in Deutschland: eine Bilanz, Beiträge zur Hochschulforschung 31 (2), 8-20.

Lindberg, M. (2007). "At the Frontier of Graduate Surveys" Assessing Participation and Employability of Graduates with Master's Degree in nine European Countries, Higher Education 53, 623-644.

Nauck, B., Diefenbach, H., and Petri, K. (1998). Intergenerationale Transmission von kulturellem Kapital unter Migrationsbedingungen: Zum Bildungserfolg von Kindern und Jugendlichen aus Migrantenfamilien in Deutschland, Zeitschrift für Pädagogik 98 (5), 701-722.

Peers, I., and Johnston, M. (1994). Influence of Learning Context on the Relationship between A-Level Attainment and Final Degree Performance: A Meta-analytic Review, British Journal of Educational Psychology 64 (1), 1-18.

Pilz M. (2009). After Abitur, first an apprenticeship and then university? Why German Abitur 
holder are taking vocational training in the financial services sector, European Journal of Vocational Training 46 (1), 41-65.

Rumberger, R. and Scott, L. (1993). The Economic Returns to College Major, Quality and Performance: A Multilevel Analysis of Recent Graduates, Economics of Education Review 12 (1), 1-19.

Sacerdote, B. (2001). Peer Effects with Random Assignment: Results for Dartmouth Roommates, Quarterly Journal of Economics 116 (2), 681 - 704.

Santor, D., Messervey, D., Kusumakar, V. (2000). Measuring peer pressure, popularity, and conformity in adolescent boys and girls: predicting school performance, sexual attitudes, and substance abuse, Journal of Youth and Adolescence 29(2), 163 - 182.

Sirin, D. (2005). Socioeconomic Status and Academic Achievement: A Meta-Analytic Review of Research. Review of Educational Research 75 (3), 417-453.

Sund, K. (2009). Estimating Peer Effects in Swedish High School Using School, Teacher, and Student Fixed Effects, Economics of Education Review 28 (3), 329-336.

Trapmann, S., Hell, B., Weigand, S., Schuler, H. (2007). Die Validität von Schulnoten zur Vorhersage des Studienerfolgs - eine Metaanalyse, Zeitschrift für pädagogische Psychologie 21 (1), 11-27.

Walberg, H., and Weinstein, T. (1984). Adult Outcomes of Connections, Certification, and Verbal Competence, Journal of Educational Research 77 (4), 207-212.

Winston, G. (1999). Subsidies, Hierarchy and Peers: The Awkward Economics of Higher Education, Journal of Economic Perspectives 13 (1), 13-36.

Wintre, M. G., Dilouya, B., Pancer, S. M., Pratt, M. W., Birnie-Lefcovitch, S. Polivy, and J., Adams, G. (2011). Academic achievement in first-year university: who maintains their high school average?, Higher Education 62, 467-481.

Wise, D. (1975) Academic Achievement and Job Performance, American Economic Review 65 (3), 350-366.

Zimmerman, D. (2007). Peer Effects in Academic Outcomes: Evidence from a Natural Experiment, Review of Economics and Statistics 85 (1), 9-23. 


\section{Appendix}

\begin{tabular}{l|c|c}
\hline Subject & Number of all graduates & $\begin{array}{c}\text { Number of university diploma } \\
\text { graduates }\end{array}$ \\
\hline History & 51 & - \\
Geography & 78 & - \\
Management & 1328 & 677 \\
Economics & 104 & 97 \\
Social work & 315 & - \\
Mathematics & 67 & 65 \\
Physics & 85 & 85 \\
Psychology & 160 & 160 \\
Sociology/Political & 144 & 73 \\
Science & 950 & 184 \\
Engineering & 258 & 258 \\
Biology/Chemistry & 268 & 138 \\
Computer science & 149 & 94 \\
Education science & 128 & 89 \\
Foreign & 127 & 14 \\
languages & 137 & 51 \\
German philology & 4271 & 1985 \\
Architecture & Total &
\end{tabular}

Table A1: Number of observations by subject (all and university diploma) 


\begin{tabular}{|c|c|c|c|c|c|}
\hline Subject & $\begin{array}{c}\text { Average } \\
\text { grade higher } \\
\text { secondary } \\
\text { school } \\
\text { education }\end{array}$ & $\begin{array}{l}\text { Average study } \\
\text { grade }\end{array}$ & $\begin{array}{c}\text { Share of fathers } \\
\text { with university } \\
\text { grade }\end{array}$ & $\begin{array}{c}\text { Share of mothers } \\
\text { with university } \\
\text { grade }\end{array}$ & $\begin{array}{c}\text { Share female } \\
\text { students }\end{array}$ \\
\hline History & 2.1 & 1.6 & 0.33 & 0.22 & 0.41 \\
\hline Management & 2.3 & 2.1 & 0.25 & 0.15 & 0.51 \\
\hline Economics & 2.0 & 1.9 & 0.41 & 0.26 & 0.35 \\
\hline Social work & 2.4 & 1.8 & 0.14 & 0.10 & 0.81 \\
\hline Mathematics & 1.8 & 1.5 & 0.43 & 0.27 & 0.37 \\
\hline Physics & 1.7 & 1.4 & 0.44 & 0.33 & 0.11 \\
\hline Psychology & 1.9 & 1.5 & 0.36 & 0.18 & 0.86 \\
\hline $\begin{array}{l}\text { Sociology/Political } \\
\text { Science }\end{array}$ & 2.3 & 2.0 & 0.31 & 0.19 & 0.51 \\
\hline Engineering & 2.5 & 2.1 & 0.19 & 0.10 & 0.10 \\
\hline Biology/Chemistry & 2.1 & 1.5 & 0.33 & 0.17 & 0.52 \\
\hline Computer science & 2.2 & 1.9 & 0.28 & 0.18 & 0.18 \\
\hline Education science & 2.6 & 1.9 & 0.31 & 0.14 & 0.79 \\
\hline $\begin{array}{l}\text { Foreign } \\
\text { languages }\end{array}$ & 1.8 & 1.8 & 0.45 & 0.28 & 0.86 \\
\hline German philology & 2.2 & 1.9 & 0.39 & 0.22 & 0.82 \\
\hline Architecture & 2.3 & 2.2 & 0.32 & 0.15 & 0.49 \\
\hline Total & 2.3 & 1.9 & 0.27 & 0.16 & 0.45 \\
\hline
\end{tabular}




\begin{tabular}{|c|c|c|}
\hline & (1) & (2) \\
\hline \multicolumn{3}{|l|}{ Average student characteristics } \\
\hline \multirow[t]{2}{*}{ Fathers with university education } & -0.418 & -0.094 \\
\hline & $(0.510)$ & $(0.499)$ \\
\hline \multirow[t]{2}{*}{ Mothers with university education } & 0.774 & 0.235 \\
\hline & $(0.885)$ & $(1.081)$ \\
\hline \multirow[t]{2}{*}{ Average grade in higher secondary education } & $-0.245 * *$ & $-0.228 * *$ \\
\hline & $(0.103)$ & $(0.093)$ \\
\hline \multirow[t]{2}{*}{ Average number of semesters } & & $-0.099 * * *$ \\
\hline & & $(0.028)$ \\
\hline \multirow[t]{2}{*}{ Share female students } & & 0.034 \\
\hline & & $(0.107)$ \\
\hline \multirow[t]{2}{*}{ Share students with apprenticeship training } & & 0.276 \\
\hline & & $(0.445)$ \\
\hline \multirow[t]{2}{*}{ Share students with foreign study } & & 0.100 \\
\hline & & $(0.087)$ \\
\hline \multirow[t]{2}{*}{ Share old students } & & -0.710 \\
\hline & & $(0.903)$ \\
\hline \multirow[t]{2}{*}{ Share young students } & & 0.263 \\
\hline & & $(1.092)$ \\
\hline \multirow[t]{2}{*}{ Share students with children } & & 0.487 \\
\hline & & $(1.336)$ \\
\hline
\end{tabular}

Broad basic knowledge

0.172

(1.526)

Specific knowledge in my study field

$-0.221$

(0.440)

Theoretical knowledge in my study field

0.398

(0.874)

Knowledge in scientific methods

0.532

(2.846)

Foreign languages

0.133

(0.367)

Independent work

0.296

(1.464)

Communication skills

$-0.341$

(1.573)

Problem solving skills

$0.575^{* *}$

(0.210)

Organisation skills

$-0.693$

(1.250)

Information and communication technology skills

$-0.111$

(0.684)

0.697

Written expression skills

(1.418)

$-1.474$

(6.395)

0.906

(3.516)

$-0.901 * * *$

(0.332) 


\section{Average study finance}

Share students with employment

Share students with public subsidy

Share students with public subsidy

Share students with grant

Share students finance by parents

Share students with bank credit

0.399

\begin{tabular}{lcccc}
\hline Nine individual characteristics & Yes & Yes & Yes & Yes \\
Five study financing characteristics & Yes & Yes & Yes & Yes \\
15 self-assessed skill dimensions & Yes & Yes & Yes & Yes \\
\hline 10 university dummies & Yes & Yes & Yes & Yes \\
16 university of applied sciences dummies & Yes & Yes & Yes & Yes \\
\hline R-squared & $20.08 \%$ & $21.39 \%$ & $21.56 \%$ & $20.96 \%$ \\
Observations & 4,250 & 4,250 & 4,250 & 4,250 \\
\hline
\end{tabular}

Table A3: Dependent variable: Deviation from subject mean final grade. Standard errors in parentheses $\left({ }^{* * *} p<0.01,{ }^{* *} p<0.05,{ }^{*} p<0.1\right)$, all columns full sample 